\title{
Human pressures on UK seabed habitats: a cumulative impact assessment
}

\author{
Jo Foden ${ }^{1, *}$, Stuart I. Rogers ${ }^{2}$, Andrew P. Jones ${ }^{1}$ \\ ${ }^{1}$ School of Environmental Sciences, University of East Anglia, Norwich, Norfolk NR4 7TJ, UK \\ ${ }^{2}$ Centre for Environment, Fisheries and Aquaculture Science (Cefas), Pakefield Road, Lowestoft, Suffolk NR33 0HT, UK
}

\begin{abstract}
European Member States are required to assess the status of marine waters, including analysis of cumulative effects. We developed a methodology for evaluating the impact of several human activities that constitute 4 direct pressures on the UK (England and Wales) seabed community: smothering, abrasion, obstruction (sealing), and extraction. The method was tested by mapping the spatial extent of individual and cumulative activities for 2007 by habitat type, quantifying the intensity of activities, and estimating impact using published recovery times. More than half $\left(134400 \mathrm{~km}^{2}\right)$ of the seabed was directly affected by human activities, of which only $165 \mathrm{~km}^{2}(<0.1 \%)$ was occupied by multiple activities. Benthic fishing accounted for $99.6 \%$ of the spatial footprint. Sensitivity to the pressures of human activities varied by habitat type, with estimated recovery times ranging from $<1$ mo for otter trawling in sand, to $\sim 15 \mathrm{yr}$ for co-occurring aggregate extraction and dredge material disposal in low-energy gravel habitat. Fully integrated, dynamically-linked environmental assessments are generally considered desirable for greater scientific understanding of an ecosystem. The methodology we present for quantifying cumulative effects is a step towards this. However, our findings indicate that a limited number of activities were the predominant cause of widespread, long recovery times of benthic fauna. This suggests that when time and resources are limited, single sector assessment rather than detailed evaluation of cumulative effects, can still usefully guide management. As the observed cumulative effects were primarily related to a few activities, it might reasonably be argued that management effort should be focused on spatially extensive activities, such as benthic fishing to mitigate most of the human impact on the UK seabed.
\end{abstract}

KEY WORDS: Abrasion · Cumulative impact · Extraction · Marine habitats · Obstruction · Recovery · Smothering $\cdot$ UK seabed Resale or republication not permitted without written consent of the publisher

\section{INTRODUCTION}

The UK has commitments to monitor and assess the condition of the marine environment under several international conventions and Directives, including the United Nations Convention on biological diversity (UNEP 1992), the OSPAR Convention for the protection of the North-East Atlantic, and the Habitats (EU 1992), Birds (EU 2010) and Water Framework (EU 2000) Directives. Added to these is the new European Marine Strategy Framework Directive (MSFD), which requires member states to make an assessment of their marine waters with a requirement to achieve Good
Environmental Status by 2020 (EU 2008). The recently published Charting Progress 2 (CP2) report was compiled to address many of the obligations under these initiatives and regulations by providing robust evidence for the current and projected state of the marine environment (Defra 2010). However, the conclusions that could be drawn were limited. The authors reported that they had low confidence in the assessment of shallow subtidal sediment habitats and that this was because of a lack of knowledge, data and assessment tools. These habitats, defined as sand, gravel, mud and mixed sediments that are affected by wave action, constitute the majority of the seabed of 
England and Wales (Fig. 1). Only 10\% of the seabed was assessed using habitat maps and the remainder was modelled. Furthermore, the authors highlighted the severe lack of understanding regarding the links between human activities and the marine environment. Most significantly there was little understanding of the cumulative impact of several activities in one area and the ability of a species or habitats to recover once a pressure has been removed.

In this paper we address some of these knowledge gaps, with particular reference to the requirements of the MSFD. The Directive requires member states to assess predominant pressures and impacts, including cumulative and synergetic effects. Apart from naturally occurring near-bed currents and wind-induced waves (Hall 1994), the major sources of seabed disturbance in UK waters are caused by human activities (Foden et al. 2010). Under the MSFD, human activities are grouped into generic pressure types, which are useful because ecosystems respond to types of pres-

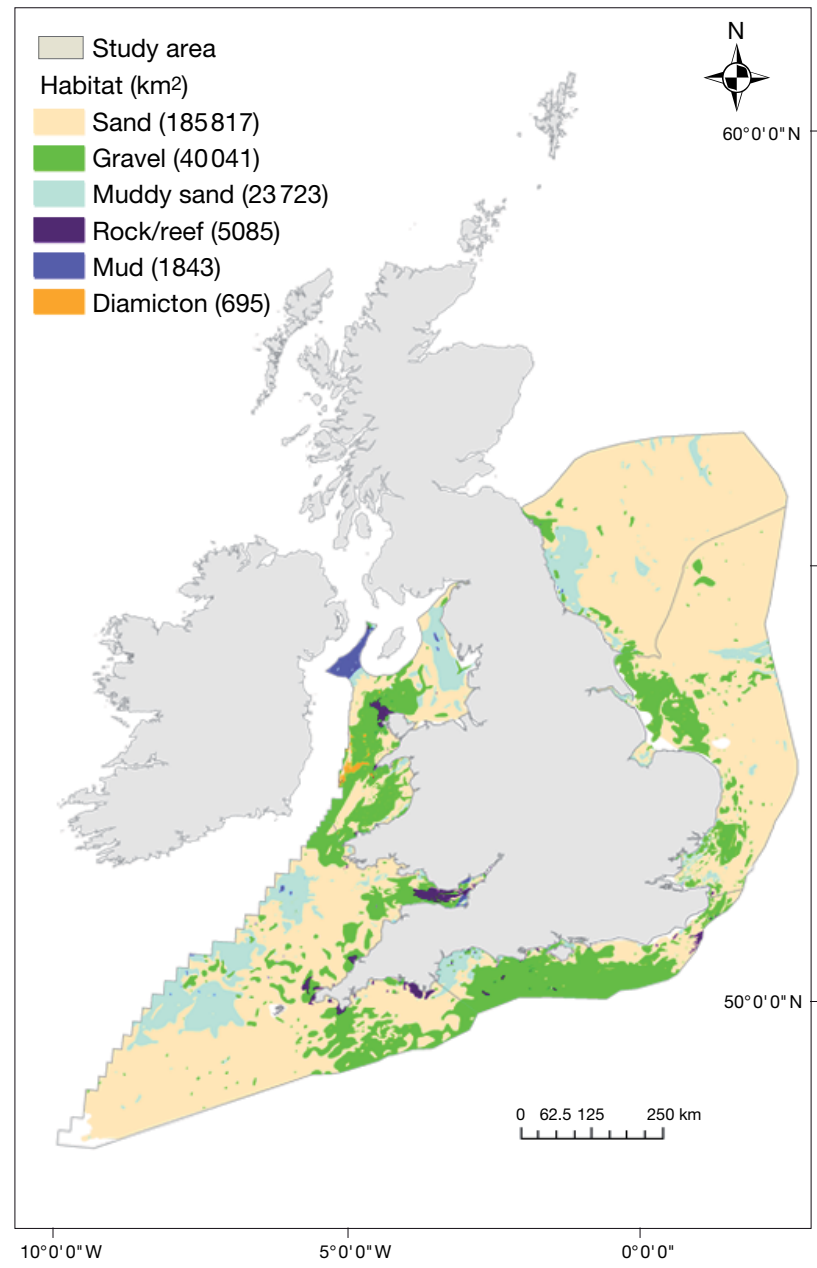

Fig. 1. Study area. UK (England and Wales) seabed habitat types - Charting Progress reporting area sure rather than specific activities. Pressures directly affecting the seabed are physical loss (smothering and obstruction) and physical damage (siltation, abrasion, and extraction). The MSFD defines and lists examples of activities causing such pressures. From these we considered the following 4 pressures caused by 12 activities which occur in UK (England and Wales, E\&W) waters:

- Smothering: covering the natural seabed habitat with a layer of material which, under some circumstances, might be expected to disperse. Smothering activities include disposal of dredged material and cuttings from oil and gas exploration

- Obstruction (termed 'sealing' in the MSFD): permanent structures fixed on the seabed. Obstruction activities include oil and gas platforms, well heads, oil and gas pipelines, telecommunication and power cables, wind turbines, and wrecks

- Abrasion: scouring and ploughing of the seabed. Abrasion activities include benthic fishing using trawl gear, burying activity during telecommunication and power cable laying, and wind turbine scour

- Extraction: exploitation by removal of seabed resources. Aggregate extraction is the only activity in this pressure type.

Habitats vary in their sensitivity to disturbance from different pressures. Investigations of seabed recovery rates following disturbance provide a method of quantitatively estimating habitat sensitivity (Desprez 2000, Cooper et al. 2007, Foden et al. 2009, 2010). Habitats requiring long recovery periods might be considered more sensitive than those with more rapid recovery rates. If a pressure occurs too frequently for a habitat to recover, the benthic community's biomass and productivity decline (Hiddink et al. 2006a) and sustainability may be jeopardised. Defining benthic recovery from any type or scale of pressure is problematic. Ecosystem recovery is complex with a range of definitions and metrics used, and existing scientific studies have limitations in their scope (Gilkinson et al. 2005, Hall et al. 2008). This is because complete recovery would be the return of an ecosystem to its original, pre-disturbance state, whereby the abundance, diversity, structure and functioning of the biological community are the same as prior to the disturbance (Hiscock \& Tyler-Walters 2006). However, this is unrealistic and most studies focus on the recovery of the key species, assemblages and components of the ecosystem (Hall et al. 2008).

The cumulative effects of coinciding pressures can be additive, antagonistic, or synergistic. Antagonism is a cumulative impact value lower than the sum of individual impacts, and synergy is a value greater than the sum of individual impacts (Folt et al. 1999). These can be difficult to predict (Crain et al. 2008, Darling \& Côté 2008). Consequently, with a few notable exceptions 
(e.g. Stelzenmüller et al. 2010), most previous regional and global scale studies have been limited to assuming cumulative pressures are additive and have presented relative, rather than actual, impacts (e.g. Halpern et al. 2008b). Quantifying the capacity for habitats to withstand pressures has been identified as a critical step for better understanding of ecosystem resilience (Ban et al. 2010) and will help inform decision-makers in facilitating an ecosystem approach to marine management.

Our study builds on the innovative earlier work of Eastwood et al. (2007), who mapped human activities in UK (England and Wales) waters, and Stelzenmüller et al. (2010), who analysed spatial pressures and marine habitat sensitivity by running scenarios to estimate risk of cumulative impacts. Our objective was to develop a method for examining whether cumulative effects are of spatial or temporal concern in UK waters. To do this, we conducted a 'dynamically linked ecosystem assessment' (Foden et al. 2008) for a range of different sectors by (1) mapping the spatial extent of human activities in 2007 at a high resolution; (2) using data on habitat recovery periods as indicators of sensitivity and estimating the proportion of habitats in which recovery would be possible at 2007 levels of activity; (3) investigating where pressures coincided, potentially giving rise to cumulative impacts on the seabed; and (4) where pressures overlap, estimating overall recovery times for 4 cumulative effects scenarios - greatest, additive, antagonistic, and synergistic (e.g. Crain et al. 2008, Darling \& Côté 2008, Halpern et al. 2008a, Foden et al. 2010).

\section{METHODS}

Study area and habitats. The study area (Fig. 1) comprised the marine waters of the UK (E \& W), as delineated for environmental status reporting under Charting Progress (Defra 2005). Five habitat types were identified, based on the largest proportion of constituent particle size: mud, muddy sand, sand, gravel, and reef/rock (including biogenic habitats constructed or composed primarily of living biota). These incorporate European Nature Information System (EUNIS) habitats A5.1, A5.2, A5.3, A5.4, A5.5 and A5.6 (EEA 2004). The habitat types are relevant to the impact of human activities on the seabed (Collie et al. 2000, Kaiser et al. 2006, Pitcher et al. 2009, Foden et al. 2010). Together the habitats constitute $>99 \%$ of the UK seabed with diamicton (matrix of large and fine grains) or unclassified sediment accounting for the remainder.

Spatial data and processing. To conduct a pressure assessment of human impacts on the seabed, spatial data were collated for 4 pressures and associated activities listed above (Table 1). We used data from 2007 for compatibility with previous impact assessment work (Foden et al. 2009, 2010). Records for each activity were joined to British Geological Survey sediment types (Folk 1954) using the ESRI ArcGIS Geographical Information System (ESRI) and grouped to the habitat types listed above.

The 2 main causes of smothering in UK waters are the disposal of material from harbour dredging (creating dredging spoils) and the discharge of drill cuttings at oil and gas platform drilling rigs. Disposal occurs in defined licensed areas and licensees are generally guided to dispose of material in the centre of the site in an attempt to restrict plumes (S. Pacitto pers. comm.). When an oil or gas well is drilled, waste cuttings are separated on the platform and are normally discharged to the seabed (Kingston et al. 1987, Breuer et al. 2004). By January 2001 oil- and synthetic-based muds could no longer be released into the environment (OSPAR Commission 2000, 2009). We assumed that during the intervening decade, recovery from drilling with these muds will have occurred (Daan \& Mulder 1996). Consequently only the effects of water-based muds (WBM) cuttings were considered for well heads and platforms in operation during or since 2001. Although cuttings piles will vary in size and shape, WBM-contaminated cuttings have been reported to reach approx. $100 \mathrm{~m}$ from the well (Daan \& Mulder 1996, Currie \& Isaacs 2005, Zuvo et al. 2005), which we used as a standard dimension.

Potential causes of obstruction in UK waters include oil and gas platforms, well head protective structures, pipelines, exposed cables, wind farm turbines, and wrecks. Individual platforms, well head structures, wind turbine scour protection, and wrecks vary in size and shape, but as specific information was not available, we used standard dimensions to generate representative footprints (spatial extent estimates) for these activities (Table 1). Dimensions were available for individual pipelines and armoured telecommunication cables overlying rock so their footprints could be accurately represented. In soft sediment telecommunication cables are generally buried, but to account for the remainder, we assumed $\sim 20 \%$ was exposed and used a standard cable width (R. Hill pers. comm.).

Abrasion in UK waters is caused by benthic fishing, wind turbine foundation scour, and burial of power cables. The most important human pressure, in terms of spatial extent and level of impact, results from fishing using benthic trawl gear such as beam trawlers, otter trawlers, and shellfish dredges (e.g. Collie et al. 1997, Rijnsdorp et al. 1998, Dinmore et al. 2003, Stelzenmüller et al. 2008). Recovery from fishing is geardependent and may also depend on frequency of trawl passes (Kaiser et al. 2006, Hall et al. 2008). We used published estimates of spatial variability and intensity 
Table 1. Pressures and activities affecting the UK seabed. Data provided in WGS 84 (world geodetic system 1984) projection in decimal degrees (6 decimal places; Cefas, SPIRE, SeaZone, UKHO), or British National Grid eastings and northings at ordinate resolution $0.0001 \mathrm{~m}$ (UK DEAL). Cefas: Centre for Environment Fisheries and Aquaculture Science; SPIRE: Shared Spatial Information Services (https://secure.services.defra.gov.uk/); UK DEAL: United Kingdom Offshore Oil \& Gas Industry, Common Data Access Ltd. (www.ukdeal.co.uk); UKCPC: United Kingdom Cable Protection Company (www.ukcpc.org.uk); SeaZone: British Crown and SeaZone Solutions Limited; UKHO: United Kingdom Hydrographic Office

\begin{tabular}{|c|c|c|c|c|}
\hline $\begin{array}{l}\text { Pressures and } \\
\text { activities }\end{array}$ & $\begin{array}{l}\text { Data source \& } \\
\text { description }\end{array}$ & Activity description & $\begin{array}{l}\text { Manipulation in GIS and } \\
\text { footprint area }\end{array}$ & References \\
\hline $\begin{array}{l}\text { Smothering } \\
\text { Disposal of } \\
\text { dredged } \\
\text { material }\end{array}$ & $\begin{array}{l}\text { Cefas, } \\
\text { SPIRE. } \\
\text { Licence area } \\
\text { polygons }\end{array}$ & $\begin{array}{l}\text { Disposal occurs within }>150 \\
\text { licensed sites. Licensees } \\
\text { deposit material over the } \\
\text { centre of sites }\end{array}$ & $\begin{array}{l}\text { Dimensions of licensed } \\
\text { disposal sites, without } \\
\text { buffers }\end{array}$ & $\begin{array}{l}\text { Bolam et al. (2006), } \\
\text { Birchenough et al. }(2010) \\
\text { S. Pacitto (pers. comm.) }\end{array}$ \\
\hline $\begin{array}{l}\text { Cuttings from } \\
\text { oil and gas } \\
\text { exploration }\end{array}$ & $\begin{array}{l}\text { SPIRE, } \\
\text { UK DEAL. } \\
\text { Point data }\end{array}$ & $\begin{array}{l}\text { Cuttings are produced during } \\
\text { drilling. Cuttings are separated } \\
\text { and disposed to sea. Since } 2000 \\
\text { only water-based fluid has been } \\
\text { permitted for drilling }\end{array}$ & $\begin{array}{l}\text { Circular buffers of } 100 \mathrm{~m} \\
\text { radius applied to platform } \\
\text { and well head data. Area } \\
\text { of } \sim 31500 \mathrm{~m}^{2} \text { per point }\end{array}$ & $\begin{array}{l}\text { OSPAR Commission (1993, } \\
\text { 2000, 2009), Daan \& Mulder } \\
\text { (1996), de Groot (1996), } \\
\text { Currie \& Isaacs (2005), } \\
\text { Eastwood et al. (2007), R. S. } \\
\text { Rowles (pers. comm.) }\end{array}$ \\
\hline \multicolumn{5}{|c|}{ Obstruction (sealing) } \\
\hline $\begin{array}{l}\text { Oil and gas } \\
\text { platforms }\end{array}$ & $\begin{array}{l}\text { SPIRE, } \\
\text { UK DEAL. } \\
\text { Point data }\end{array}$ & $\begin{array}{l}\text { Four- or 6-leg steel structures, } \\
\text { each } 2 \text { m diameter. Plus } \\
\text { associated drilling and } \\
\text { production gear }\end{array}$ & $\begin{array}{l}\text { Circular buffers of } 7.5 \mathrm{~m} \\
\text { radius applied. Area of } \\
180 \mathrm{~m}^{2} \text { per platform }\end{array}$ & $\begin{array}{l}\text { UKOOA (2002), } \\
\text { Eastwood et al. (2007) }\end{array}$ \\
\hline Well heads & $\begin{array}{l}\text { SPIRE, } \\
\text { UK DEAL. } \\
\text { Point data }\end{array}$ & $\begin{array}{l}\text { Protective structures built over } \\
\text { well heads }\end{array}$ & $\begin{array}{l}\text { Circular buffers of } 25 \mathrm{~m} \\
\text { radius applied to point data. } \\
\text { Area of } \sim 2000 \mathrm{~m}^{2} \text { per well } \\
\text { head }\end{array}$ & Eastwood et al. (2007) \\
\hline $\begin{array}{l}\text { Oil and gas } \\
\text { pipelines }\end{array}$ & $\begin{array}{l}\text { SPIRE, } \\
\text { UK DEAL. } \\
\text { Line data }\end{array}$ & $\begin{array}{l}\text { Pipelines resting on the surface } \\
\text { of seabed }\end{array}$ & $\begin{array}{l}\text { Exact dimensions of } \\
\text { pipelines }\end{array}$ & Eastwood et al. (2007) \\
\hline $\begin{array}{l}\text { Telecommu- } \\
\text { nication and } \\
\text { power cables }\end{array}$ & $\begin{array}{l}\text { SPIRE, } \\
\text { SeaZone, } \\
\text { UKHO. } \\
\text { Line data }\end{array}$ & $\begin{array}{l}\text { Exposed cables on rock are } \\
\text { armoured to a maximum dia- } \\
\text { meter of } 50 \mathrm{~mm} \text {. Approx } 20 \% \\
\text { cables in soft sediment are not } \\
\text { buried }\end{array}$ & $\begin{array}{l}\text { Buffers } 50 \mathrm{~mm} \text { wide for } \\
\text { cables on rock substrate and } \\
25 \mathrm{~mm} \text { on soft sediment }\end{array}$ & $\begin{array}{l}\text { Kogan et al. (2006), } \\
\text { Carter et al. (2009), } \\
\text { R. Hill (pers. comm.), } \\
\text { UKCPC }\end{array}$ \\
\hline $\begin{array}{l}\text { Wind } \\
\text { turbines }\end{array}$ & $\begin{array}{l}\text { Crown Estate, } \\
\text { SPIRE, } \\
\text { SeaZone. } \\
\text { Point data }\end{array}$ & $\begin{array}{l}\text { Monopile foundations } 4-5 \mathrm{~m} \\
\text { in diameter with scour } \\
\text { protection of } 30 \mathrm{~m} \text { diameter }\end{array}$ & $\begin{array}{l}\text { Circular buffers of } 15 \mathrm{~m} \\
\text { radius applied. Area of } \\
\sim 700 \mathrm{~m}^{2} \text { per turbine }\end{array}$ & $\begin{array}{l}\text { OSPAR Commission (2006), } \\
\text { Rees (2006) }\end{array}$ \\
\hline Wrecks & $\begin{array}{l}\text { SPIRE, } \\
\text { SeaZone, } \\
\text { UKHO. } \\
\text { Point data }\end{array}$ & $\begin{array}{l}\text { Sizes of individual wrecks } \\
\text { unknown. Nominal spatial } \\
\text { extent used }\end{array}$ & $\begin{array}{l}\text { Circular buffers of } 17.5 \mathrm{~m} \\
\text { radius applied. Area of } \\
962 \mathrm{~m}^{2} \text { per wreck }\end{array}$ & Eastwood et al. (2007) \\
\hline \multicolumn{5}{|l|}{ Abrasion } \\
\hline $\begin{array}{l}\text { Benthic } \\
\text { fishing } \\
\text { using trawl } \\
\text { gear }\end{array}$ & $\begin{array}{l}\text { Cefas. } \\
\text { Point data }\end{array}$ & $\begin{array}{l}\text { Vessels } \geq 15 \mathrm{~m} \text {. Satellite-based } \\
\text { Vessel Monitoring Systems (VMS) } \\
\text { point data. UK logbook data and } \\
\text { the European vessel register for } \\
\text { type of gear deployed; grouped } \\
\text { as otter trawls, beam trawls or } \\
\text { shellfish dredges }\end{array}$ & $\begin{array}{l}\text { Estimates of spatial extent } \\
\text { of fishing for each VMS } \\
\text { record based on vessel } \\
\text { speed, VMS interval and } \\
\text { width of fishing gear. Data } \\
\text { gridded in } 1 \mathrm{~km}^{2} \text { cells. Inten- } \\
\text { sity calculated from annual } \\
\text { number of trawl passes }\end{array}$ & $\begin{array}{l}\text { Collie et al. (1997), } \\
\text { Rijnsdorp et al. (1998), } \\
\text { Dinmore et al. (2003), } \\
\text { Stelzenmüller et al. (2008), } \\
\text { Foden et al. (2010) }\end{array}$ \\
\hline $\begin{array}{l}\text { Telecommu- } \\
\text { nication and } \\
\text { power cables }\end{array}$ & $\begin{array}{l}\text { SPIRE, } \\
\text { SeaZone, } \\
\text { UKHO. } \\
\text { Line data }\end{array}$ & $\begin{array}{l}\text { Fibre-optic cables } 17-21 \mathrm{~mm} \text { dia- } \\
\text { meter, protected to a total dia- } \\
\text { meter of } 30 \mathrm{~mm} \text {. Buried in soft sedi- } \\
\text { ment by sea plough or water jet }\end{array}$ & $\begin{array}{l}\text { Buffers } 5 \mathrm{~m} \text { wide represen- } \\
\text { ting the mean width of } \\
\text { trench disturbance }\end{array}$ & $\begin{array}{l}\text { Allan (1998), Carter et al. } \\
\text { (2009), Drew \& Hopper } \\
\text { (2009), UKCPC }\end{array}$ \\
\hline $\begin{array}{l}\text { Wind turbine } \\
\text { scour }\end{array}$ & $\begin{array}{l}\text { Crown Estate, } \\
\text { SPIRE, } \\
\text { SeaZone. } \\
\text { Point data }\end{array}$ & $\begin{array}{l}\text { Waves and tides around turbines } \\
\text { cause scour pits in mobile } \\
\text { sediment, up to } 10 \text { times the dia- } \\
\text { meter of the obstruction }\end{array}$ & $\begin{array}{l}\text { Circular buffers of } 50 \mathrm{~m} \\
\text { radius applied. Area of } \\
\sim 7850 \mathrm{~m}^{2} \text { per turbine, minus } \\
\text { area of scour protection } \\
\text { (see Obstruction) }\end{array}$ & Rees (2006) \\
\hline $\begin{array}{l}\text { Extraction } \\
\text { Aggregate } \\
\text { extraction }\end{array}$ & $\begin{array}{l}\text { Crown Estate, } \\
\text { Cefas, SPIRE. } \\
50 \times 50 \mathrm{~m} \\
\text { polygons }\end{array}$ & $\begin{array}{l}\text { Electronic Monitoring Systems } \\
\text { (EMS) data in } 50 \times 50 \mathrm{~m}\left(2500 \mathrm{~m}^{2}\right) \\
\text { cells showing location and hours } \\
\text { dredged per year }\end{array}$ & $\begin{array}{l}\text { EMS } 50 \times 50 \mathrm{~m} \text { cell locations } \\
\text { and dredge intensity }\end{array}$ & $\begin{array}{l}\text { Dickson \& Lee (1972), Kenny } \\
\text { \& Rees (1994), Newell et al. } \\
\text { (1998), Boyd et al. (2004), } \\
\text { BMAPA (2006, 2008), Foden } \\
\text { et al. (2009, 2010), K. O'Shea } \\
\text { (pers. comm.) }\end{array}$ \\
\hline
\end{tabular}


of fishing activity in UK waters in 2007 (Foden et al. 2010). Intensity was accounted for as follows: e.g. if a beam trawler sweeps the entire area of a $1 \mathrm{~km}^{2}$ cell 4 times a year, fishing intensity was set to be 4.0 and the mean recovery time for the cell was estimated as the recovery time from one pass $\times 4$ (sensu Foden et al. 2010). Abrasion caused by hydrodynamics around individual turbine foundations can create scour pits of 100 m diameter (Rees 2006), which we used as a standard footprint for all turbines. The majority of offshore cables in UK waters are buried using sea-ploughs or water jets (Allan 1998, Carter et al. 2009, Drew \& Hopper 2009). The overall disturbance strip ranges from 2 to $8 \mathrm{~m}$ (Carter et al. 2009), and we used a mean width for all buried cables.

Aggregate dredging for mineral resources constitutes extraction pressure in UK waters. We used published estimates of aggregate extraction effort in UK waters during 2007 (Foden et al. 2009).

With GIS, estimations were made of the location and areas of seabed habitats affected by individual and by coincidental activities. Activities were also grouped by the 4 pressure categories to estimate the location and areas affected by individual or cumulative pressures. The footprint estimates of each activity were attributed a confidence rating on a scale of 1 to 3 : 1 indicating the highest confidence rating in which location and extent of an activity's footprint were accurately known, 2 indicating known location but estimated extent, and 3 indicating the lowest confidence based on estimations of location and extent (sensu Eastwood et al. 2007).

Recovery. We estimated seabed habitat sensitivity to different anthropogenic activities by determining recovery rates of the benthic community following cessation of an activity, and based on the activity's distribution and intensity. Recovery was characterised as having occurred when the abundance, species richness or biomass of benthic biota was equivalent to a $20 \%$ reduction or less in the pre-impact value (Kaiser et al. 2006) or a return of benthic resources to either a baseline (pre-impact) or reference condition (Wilber et al. 2008). Recently published estimates of habitat recovery after aggregate extraction (Foden et al. 2009) and benthic fishing (Foden et al. 2010) were used. A review was conducted of scientific literature for recovery of the benthos from the remaining human activities. Our study area is in temperate waters where primary and secondary production are high with strong seasonal patterns, so data from studies conducted in this, or similar areas, were used. UK waters have a long history of high levels of human activity, with many pressures tending to repeatedly target the same grounds year after year (Kaiser et al. 2002, Hiddink et al. 2006b). For some habitats therefore, the point at which recovery is deemed to have occurred is a point in a constant disturbance cycle and not disturbance of a pristine benthic community.

For some activities the date of occurrence can be important when determining a site's stage of recovery. The timing of different activities was known with varying levels of precision (e.g. day or month) for 4 activities: dredge material disposal, fishing, cable burial, and aggregate extraction. This information was used to estimate the degree of recovery already reached by 2007 and to filter out activities old enough for full recovery to be assumed. Drilling dates were not available for well heads and the spatial extent of resultant cuttings piles is likely to be an overestimation, as recovery was probably well underway at sites were dispersal had occurred. Date of installation is irrelevant for areas of the seabed permanently sealed by some obstruction activities, as no recovery is possible for the duration of the activities' presence. Similarly, date of wind farm construction was not relevant for scour pits associated with turbines, as they represent a constant abrasion pressure.

Cumulative impact. The size and location of multiple activities and pressures were identified as described above. We considered activities representing obstruction pressure to be exclusive of in-combination effects. Where the seabed has been effectively sealed by an installation, benthic recolonisation is prevented and extra activities cannot have further impacts. For example, disposal may occur on top of a wreck, or a benthic fish trawl may pass over a wellhead but they can create no more damage. Within each habitat, the size and location of areas where activities coincided were estimated; the estimation of total recovery times is described below.

Where activities were coincident we estimated cumulative recovery times according to the intensity of the activity and habitat in which they occurred. Estimates were made under 4 different cumulative effects scenarios: single greatest, additive, antagonistic, and synergistic (Halpern et al. 2008a, Foden et al. 2010). This allowed us to determine the sensitivity of the scenarios to different measures of impact estimation according to habitat type. The premise for Scenario I was that the single worst or dominant pressure takes precedence over the others in determining combined effects, with lesser pressures having no additional impact. For Scenario II, multiple pressures were assumed to act independently within the system, and therefore, overall recovery time was the sum of all pressures (e.g. Halpern et al. 2008a, Ban et al. 2010).

The purpose of Scenarios III and IV was to show a range in the sensitivity of habitats to impacts that interact. Scenario III estimated cumulative impacts as the antagonistic effects of multiple pressures. Previous investigations have found marine landscapes to be 
more sensitive to some human activities than others. If pressures are applied consecutively to marine habitats, then the impact of the primary pressure may pre-condition the habitat to be less sensitive to the secondary pressure. To estimate total recovery time we used a linear calculation sensu Stelzenmüller et al. (2010): recovery time from the primary pressure $+50 \%$ recovery time from the secondary pressure, $+0 \%$ from the third pressure. Total recovery times were expected to be between those of Scenarios I and II. In Scenario IV synergistic effects were assumed, in which the impact from accumulated pressures was greater than the sum of the individual parts, the assumption being the first pressure lessens the resilience of a habitat, making it more sensitive to subsequent pressures. Therefore in Scenario IV, we estimated total recovery time using the same linear relationship: recovery from the primary pressure $+150 \%$ recovery time from secondary pres- sure $+200 \%$ from the third, with the expectation of total times greater than for the other 3 scenarios. A rank order of pressures needed to be determined for Scenarios III and IV. Stelzenmüller et al. (2010) scored the sensitivity of UK marine landscapes to a range of pressures and found that, in general, landscapes were most sensitive to extraction and were slightly more sensitive to smothering than abrasion pressures.

\section{RESULTS}

\section{Spatial distribution of pressures}

Aggregate extraction and 3 obstruction activities pipelines, cables, and wind turbines - were all at the highest confidence level (Table 2) because their location and extent were available from the data source

Table 2. Estimates of spatial extent of human activities and pressures affecting the UK seabed $\left(\mathrm{km}^{2}\right)$ in 2007 . Percentages of habitat and seabed affected are in italics. Confidence in spatial data: 1 , known location and extent; 2 , known location and estimated extent; 3, estimated location and extent

\begin{tabular}{|c|c|c|c|c|c|c|c|c|c|}
\hline \multirow{2}{*}{ Pressure } & \multirow{2}{*}{ Human activity } & \multirow{2}{*}{$\begin{array}{l}\text { Confi- } \\
\text { dence }\end{array}$} & \multirow{2}{*}{$\overline{\text { Sand }}$} & \multicolumn{3}{|c|}{ - Footprints per habitat } & \multirow[b]{2}{*}{ Mud } & \multicolumn{2}{|c|}{ Footprints on UK seabed } \\
\hline & & & & Gravel & $\begin{array}{l}\text { Muddy } \\
\text { sand }\end{array}$ & Reef & & $\begin{array}{l}\text { Per } \\
\text { activity }\end{array}$ & $\begin{array}{c}\text { Per pressure } \\
\text { (overlapping } \\
\text { activities merged) }\end{array}$ \\
\hline \multirow[t]{5}{*}{ Smothering } & \multirow[t]{2}{*}{ Dredge material disposal } & \multirow[t]{2}{*}{3} & 110.8 & 89.6 & 61.0 & 21.9 & 0.2 & 283.5 & \multirow{5}{*}{$\begin{array}{c}346.01 \\
0.14\end{array}$} \\
\hline & & & 0.06 & 0.22 & 0.26 & 0.43 & 0.01 & 0.11 & \\
\hline & \multirow{3}{*}{\multicolumn{2}{|c|}{$\begin{array}{l}\text { Cuttings from well heads and } 2 \\
\text { platforms } \\
\text { Smothering per habitat } \\
\text { (overlapping activities merged) }\end{array}$}} & 52.6 & 6.2 & 3.6 & 0.03 & 0.1 & 62.6 & \\
\hline & & & 0.03 & 0.02 & 0.02 & $<0.01$ & 0.05 & 0.02 & \\
\hline & & & 163.4 & 95.8 & 64.5 & 21.9 & 0.34 & & \\
\hline \multirow[t]{13}{*}{ Obstruction } & \multirow[t]{2}{*}{ Oil and gas platforms } & \multirow[t]{2}{*}{2} & 0.8 & $<0.1$ & $<0.1$ & 0.0 & 0.0 & 0.8 & \multirow{13}{*}{$\begin{array}{l}21.1 \\
<0.01\end{array}$} \\
\hline & & & $<0.01$ & $<0.01$ & $<0.01$ & 0.00 & 0.00 & $<0.01$ & \\
\hline & \multirow[t]{2}{*}{ Well heads } & \multirow{2}{*}{2} & 4.2 & 0.5 & 0.3 & $<0.1$ & $<0.1$ & 5.0 & \\
\hline & & & $<0.01$ & $<0.01$ & $<0.01$ & $<0.01$ & $<0.01$ & $<0.01$ & \\
\hline & \multirow[t]{2}{*}{ Oil and gas pipelines } & \multirow[t]{2}{*}{1} & 3.1 & 0.7 & 0.2 & 0.0 & $<0.1$ & 4.0 & \\
\hline & & & $<0.01$ & $<0.01$ & $<0.01$ & 0.00 & $<0.01$ & $<0.01$ & \\
\hline & \multirow[t]{2}{*}{ Submarine cables } & \multirow[t]{2}{*}{1} & 0.2 & $<0.1$ & $<0.1$ & $<0.1$ & 0.0 & 0.3 & \\
\hline & & & $<0.01$ & $<0.01$ & $<0.01$ & $<0.01$ & 0.00 & $<0.01$ & \\
\hline & \multirow[t]{2}{*}{ Wind turbines } & \multirow[t]{2}{*}{1} & 0.1 & 0.1 & 0.1 & 0.0 & 0.0 & 0.2 & \\
\hline & & & $<0.01$ & $<0.01$ & $<0.01$ & 0.0 & 0.00 & $<0.01$ & \\
\hline & \multirow[t]{2}{*}{ Wrecks } & \multirow[t]{2}{*}{2} & 6.7 & 3.4 & 1.7 & 0.4 & 0.1 & 12.4 & \\
\hline & & & $<0.01$ & $<0.01$ & $<0.01$ & $<0.01$ & $<0.01$ & $<0.01$ & \\
\hline & \multicolumn{2}{|l|}{$\begin{array}{l}\text { Obstruction per habitat } \\
\text { (overlapping activities merged) }\end{array}$} & 14.4 & 4.4 & 1.9 & 0.4 & 0.1 & & \\
\hline \multirow[t]{7}{*}{ Abrasion } & \multirow[t]{2}{*}{ Benthic fishing } & \multirow[t]{2}{*}{$2-3$} & 93946.2 & 19893.4 & 18088.2 & 647.3 & 1324.7 & 133899.7 & 133909.59 \\
\hline & & & 50.56 & 49.68 & 76.25 & 12.73 & 71.89 & 52.2 & 52.20 \\
\hline & Wind farm scour pits & 2 & 0.6 & 0.6 & 0.5 & 0.0 & 0.0 & 1.7 & \\
\hline & & & $<0.01$ & $<0.01$ & $<0.01$ & 0.00 & 0.00 & $<0.01$ & \\
\hline & Submarine cable burial & 2 & 12.3 & 4.2 & 1.4 & 0.0 & 0.1 & 18.0 & \\
\hline & & & $<0.01$ & $<0.01$ & $<0.01$ & 0.00 & $<0.01$ & $<0.01$ & \\
\hline & $\begin{array}{l}\text { Abrasion per habitat } \\
\text { (overlapping activities mergee }\end{array}$ & & 93952.3 & 19896.8 & 18089.3 & 647.3 & 1323.9 & & \\
\hline Extraction & Aggregate extraction & 1 & $\begin{array}{l}51.9 \\
0.03\end{array}$ & $\begin{array}{l}92.4 \\
0.23\end{array}$ & $\begin{array}{c}1.9 \\
<0.01\end{array}$ & $\begin{array}{l}0.0 \\
0.00\end{array}$ & $\begin{array}{l}0.0 \\
0.00\end{array}$ & $\begin{array}{c}146.3 \\
0.05\end{array}$ & $\begin{array}{c}146.3 \\
0.05\end{array}$ \\
\hline Footprint of & all pressures, per habitat & & $\begin{array}{c}94182.0 \\
50.69\end{array}$ & $\begin{array}{c}20089.5 \\
50.17\end{array}$ & $\begin{array}{c}18157.6 \\
76.54\end{array}$ & $\begin{array}{l}669.6 \\
13.17\end{array}$ & $\begin{array}{c}1324.3 \\
71.87\end{array}$ & & \\
\hline
\end{tabular}


(Table 1). The location of dredge disposal is only accurate to licence areas not the exact dumping site and this was assigned the lowest confidence rating. The location of benthic fishing vessels is provided at a 2 hourly frequency from VMS. However, in this time vessels can cover up to 12 nautical miles whilst fishing (Lee et al. 2010) and, as an estimate of the exact tracks of vessels was required for this work, confidence was rated as 2 to 3 (intermediate-to-low). Data for the remaining activities were at the intermediate confidence level because their locations were known, but the extent of impact was estimated.

The total area affected by human activity was $134400 \mathrm{~km}^{2}$, constituting $52 \%$ of the UK seabed (Table 2). Abrasion was the main pressure. Specifically, benthic fishing accounted for most of the abrasion pressure, affecting an area up to 3 orders of magnitude greater than for any other activity in any habitat. The total area affected by obstruction, extraction and smothering pressures was only $513.4 \mathrm{~km}^{2}$, constituting $\sim 0.2 \%$ of the study area. Smothering was the second largest pressure, mainly accounted for by dredge material disposal. The majority of mud and muddy sand habitats were affected by human activities, with an estimated $>70 \%$ of their area affected. Human activities occurred in approximately half of the area of sand and gravel and only $13 \%$ of reef habitats. Benthic fishing was the major cause of human pressure but its confidence rating was 2 to 3 ; thus, in general, overall confidence in the location and extent of human activity on the UK seabed in 2007 could be classed as intermediate-to-low.

In total only an estimated $166 \mathrm{~km}^{2}(0.07 \%)$ of UK seabed was affected by cumulative pressure (Table 3). Smothering, abrasion, and extraction pressures were coincident in relatively small proportions of habitat areas. Smothering and abrasion accounted for the largest areas of in-combination pressures. These 2 pressures coincided in $71 \mathrm{~km}^{2}(<0.1 \%)$ of sand, and

Table 3. Estimated areas of coincidental pressures $\left(\mathrm{km}^{2}\right)$ affecting UK seabed habitats (percentage of habitat area affected in italics)

\begin{tabular}{|lcccccc|}
\hline \multirow{2}{*}{ Coincidental pressures } & Sand & Gravel & Habitat & Muddy & Reef/ & Mud \\
\cline { 6 - 7 } & & & sand & rock & \\
\hline Smothering + abrasion & 71.1 & 10.2 & 44.6 & 0.7 & 0.1 \\
& 0.04 & 0.03 & 0.19 & 0.01 & 0.01 \\
Abrasion + extraction & 13.6 & 18.5 & 0.0 & 0.0 & 0.0 \\
Extraction + smothering & 0.01 & 0.05 & 0.00 & 0.00 & 0.00 \\
Smothering + extraction & 2.2 & 3.7 & 0.0 & 0.0 & 0.0 \\
+ abrasion & 0.1 & 0.01 & 0.01 & 0.00 & 0.00 & 0.00 \\
& $<0.01$ & $<0.01$ & 0.00 & 0.00 & 0.00 \\
\hline
\end{tabular}

$45 \mathrm{~km}^{2}(0.2 \%)$ of muddy sand. In all other cases, 2 or 3 combined pressures were coincident in $<0.1 \%$ of habitat areas.

\section{Recovery}

For reasons stated above, no recovery estimates were made for areas where the seabed was sealed by obstructions. Therefore recovery estimates are not given for locations in which oil and gas platforms, wellheads, pipelines, wind turbines, wrecks or surface laid cables were present. The precision of published recovery rates of the benthic community from the other commonly occurring human activities was variable, e.g. quoted as days, months or years. We rationalised these as months or years, so that recovery rates in Table 4 are in the range $<1$ mo to $9 \mathrm{yr}$.

The impacts on the benthos from smothering are site-specific. Recovery from dredge material disposal is context dependent and thus does not conform to a single ecological model (Bolam \& Rees 2003, Bolam et al. 2006, Whomersley et al. 2010). In general, communities adapted to strongly hydrodynamic environments recover significantly more rapidly than those in weakly hydrodynamic environments (Bolam \& Rees 2003, Bolam et al. 2006, Wilber et al. 2008). The recovery rates quoted in Table 4 are based on salinity, hydrodynamics and water depth of the receiving environment. Our estimates of recovery from cuttings contaminated with WBM were based on recovery from physical smothering, because these are quantified in the literature. However, WBM drilling wastes may contain free oil, dissolved aromatic hydrocarbons, heavy metals and radionucleides, and recent studies suggest the response of the benthic community may be through oxygen depletion (e.g. Trannum et al. 2010). However, benthic recovery has yet to be quantified. Recovery rates from physical smothering depend on particular combinations of sediment characteristics, the local hydrodynamic regime, receiving habitat, and benthic community (Kröncke et al. 1992, Daan et al. 1994, Holdway 2002, Kröncke \& Bergfeld 2003, Breuer et al. 2004). Although recovery rates were only available for sand and gravel environments, $94 \%$ of cuttings piles in the UK are in these habitats (Table 2).

Abrasion pressures may be caused by regularly-occurring, constant, or one-off activities (Table 4). Recovery rates from bottom-fishing were summarised from Foden et al. (2010), who estimated recovery of the benthos by 
Table 4. Recovery times for habitats by seabed pressure (smothering, abrasion, or extraction) and activity. Strong hydrodynamics: shallow $(\leq 20 \mathrm{~m})$, strong wave action or tidal currents, low residence time ( days), high turbidity and sediment movement. Weak hydrodynamics: $>20$ m deep, non-turbulent, low circulation sites. $\mathrm{n} / \mathrm{d}$ : no data available; $\mathrm{n} / \mathrm{r}$ : no recovery until the activity ceases; n/a: not applicable (the activity does not occur in the habitat, in UK waters)

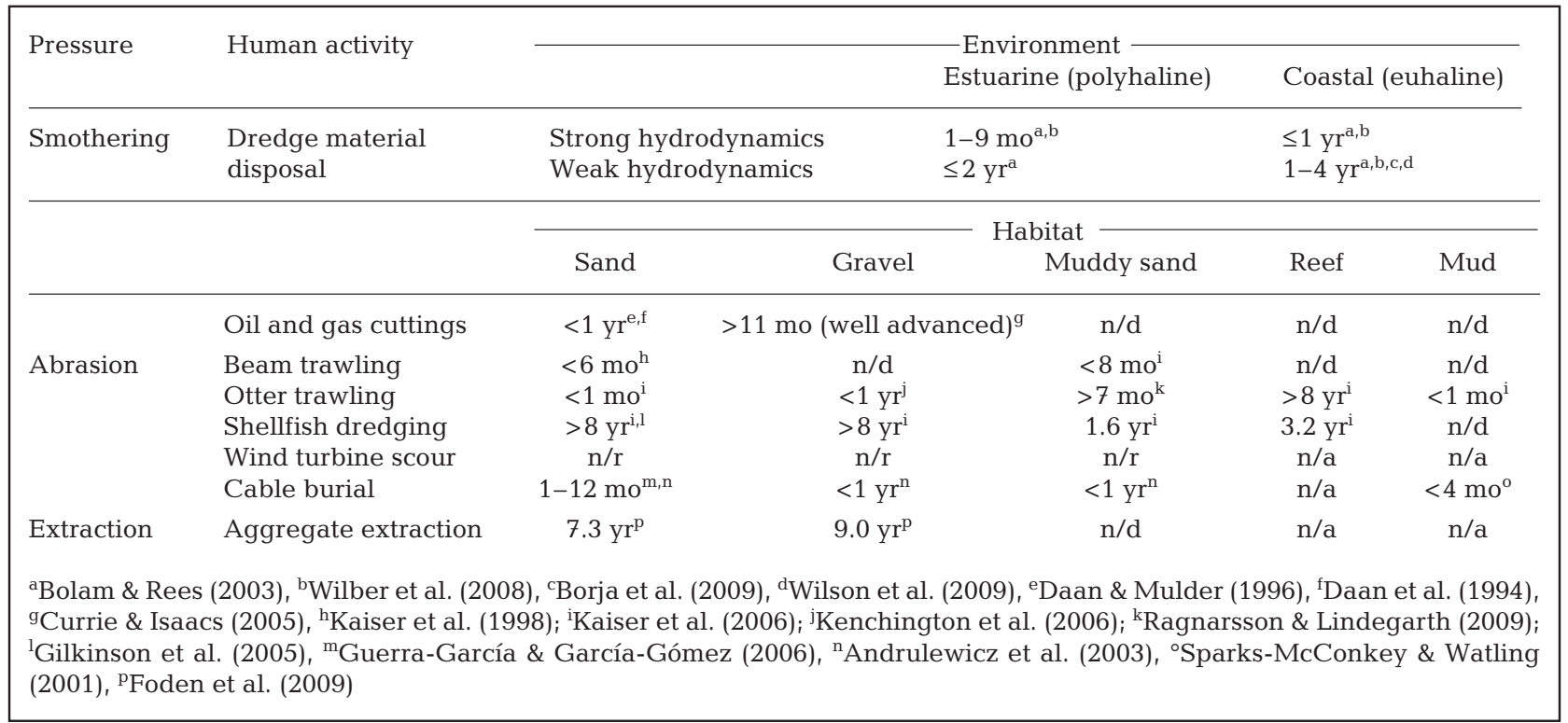

fishing gear-type and intensity. The evidence for the effects of fishing frequency is mixed, i.e. within a single habitat type the same frequency of trawl events can lead to differing responses of the benthos in different locations. Therefore we used a minimum recovery time of 1 yr in Table 5, which also allows for seasonality in the ability of the benthic community to recover (Hall et al. 2008, C. L. J. Frid pers. comm.). The habitatgear combinations for which there were no recovery rates only represent approximately $1 \%$ of the area subjected to benthic fishing in 2007. Scour pits around the foundations of wind turbines are likely to be a constant abrasion pressure. Routine sampling is not possible within $50 \mathrm{~m}$ of a turbine (OSPAR Commission 2008), so we assumed no benthic recovery is possible from scour during the lifetime of wind farms. Wind farms are licensed for $25 \mathrm{yr}$ (A. Judd pers. comm.) and to date none have been decommissioned in UK waters. Outside the scour zone, between turbines, there is little or no evidence for benthic disturbance caused by the wind farm (NPower Renewables 2008, Degraer \& Brabant 2009, Cefas 2010). Cable installation is of limited spatial and temporal extent unless a submarine cable is damaged, and recolonisation may be rapid (GuerraGarcía \& García-Gómez 2006). No data were available specifically on recovery from cable burial in mud habitats. However, a study of low intensity benthic trawling effects in a low-energy $60 \mathrm{~m}$ deep mud environment was appropriately comparable as it mirrors the mud habitat in UK waters.
The only activity representing extraction pressure is aggregate dredging. Recovery estimates in Table 4 for this activity were taken from Foden et al. (2009).

\section{Cumulative impact}

Co-occurring activities were found in all habitat types (Table 5). The footprints of coinciding activities were largest in sand $\left(87.2 \mathrm{~km}^{2}\right)$ and smallest in mud $\left(<0.1 \mathrm{~km}^{2}\right)$ habitats. However, these constitute $<0.5 \%$ of each of the 5 habitat types. Values are stated to an accuracy of $0.1 \mathrm{~km}^{2}$ to reflect the variation in confidence levels in the locational accuracy of activities and the spatial extent of their impact (from Table 2). Some combinations of activities were not found. For example, in weakly hydrodynamic estuarine environments, disposal did not occur where there were extraction or abrasion pressures. Wherever abrasion coincided with extraction or smothering, benthic fishing was the causative activity of abrasion pressure. Submarine cables and wind farm scour pits were exclusive of any other activity.

Cumulative recovery rates across the 4 scenarios ranged from $\leq 1$ to $15 \mathrm{yr}$. In Scenario I, recovery time estimates were $\leq 4 \mathrm{yr}$ for all combinations of smothering and abrasion activities, but estimates doubled (7.3 to $9 \mathrm{yr})$ where extraction comprised one of the cooccurring activities. A similar pattern was repeated for Scenarios II, III and IV; aggregate extraction consis- 


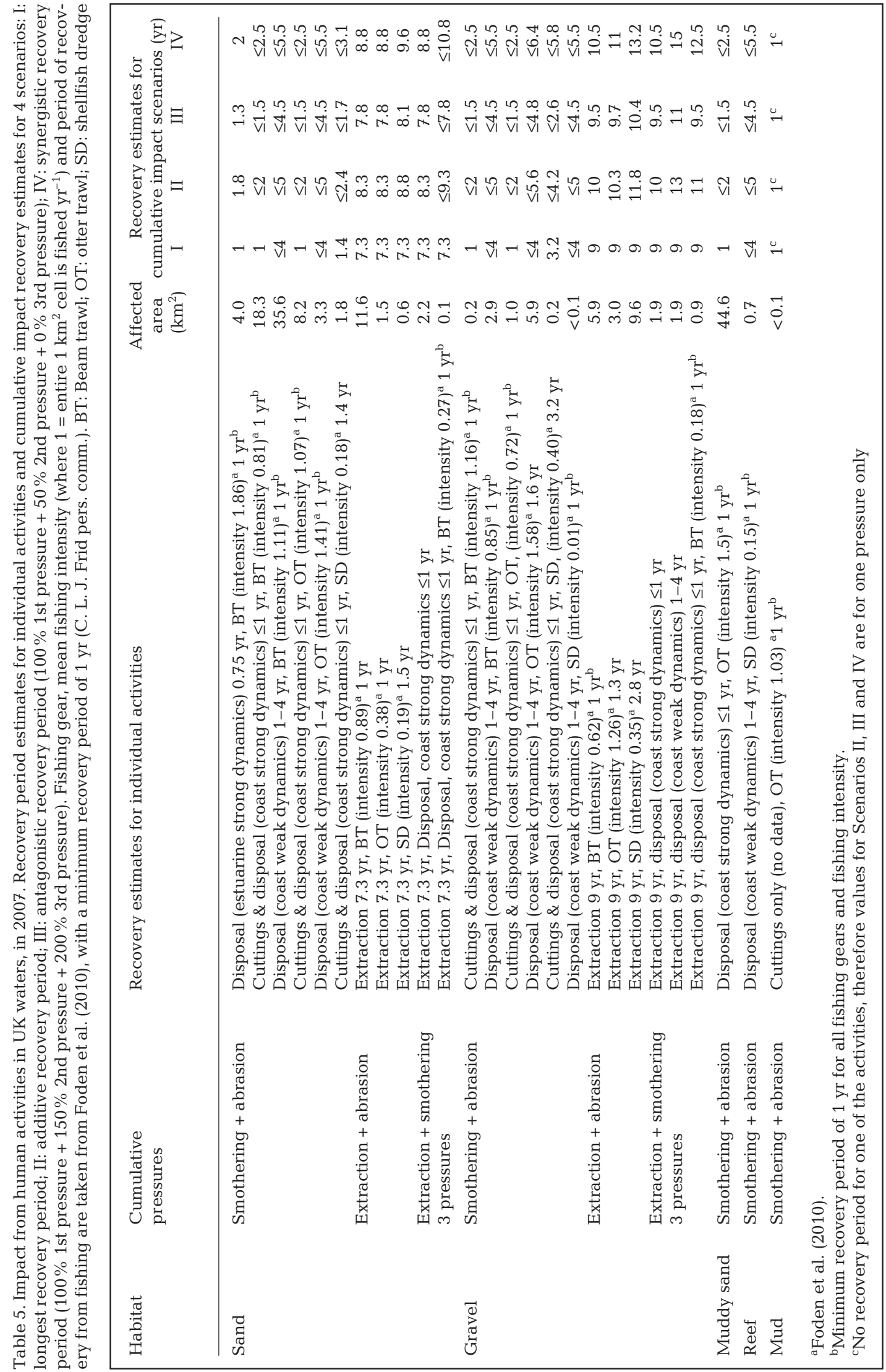


tently accounted for the longest cumulative recovery times. Consequently, sand and gravel habitats were estimated to have the longest recovery periods for Scenario IV, at up to 10 or $15 \mathrm{yr}$, respectively, because there was no aggregate extraction in the other 3 habitats. Cumulative recovery estimates were most rapid for all scenarios in muddy sand habitats (up to $2.5 \mathrm{yr}$ ), where disposal and otter trawling in a strongly hydrodynamic environment were the only coincidental activities. From the values given in Table 4 reef habitats might have been expected to recover slowly, but recovery from coincidental activities was estimated at up to $5.5 \mathrm{yr}$. The likely explanation is that scallop dredging was at the very low intensity of 0.15 (i.e. approx. once per $\mathrm{km}^{2}$ every $7 \mathrm{yr}$ ), which could allow for the benthos to begin recovering between trawls and dredge material disposal events. Mud habitat was least affected by cumulative activity $(<0.1 \%$ of habitat). Benthic recovery from drill cuttings in mud was not known, so cumulative times could not be estimated for combined smothering and abrasion pressures in this habitat. However, mud habitat only represents an area $<0.1 \mathrm{~km}^{2}$.

\section{DISCUSSION}

This study builds on previous assessment of human activities causing direct, physical pressure on the UK seabed (Eastwood et al. 2007) in 3 key ways: by quantifying the intensity of relevant activities, by linking the spatial extent of activities to habitat type, and by estimating their cumulative impact using published recovery times. Our methods and findings are relevant to several European and global obligations to assess and report marine environmental status, principally those commitments requiring greater knowledge and understanding of individual and cumulative effects from different human activities. We provide a snapshot of the spatial extent of human activities acting on the UK seabed in 2007 by applying the framework for evaluating individual and cumulative impacts proposed by Foden et al. (2010). Where activities were coincidental, 4 impact scenarios were applied to assess the range of possible consequences.

In 2007, cumulative activities were relatively rare, in total affecting an area of only $166 \mathrm{~km}^{2}(<0.1 \%$ of the study area). The majority of the footprint of human activities was caused by the activity of single, rather than multiple, sectors. Abrasion had the largest spatial extent of the 4 pressures and just one activity, benthic trawling, accounted for $99.99 \%$ of abrasion by area. Benthic fishing affected more than half of UK (E \& W) waters, as compared with $0.2 \%$ affected by all the other 11 activities combined. Inter-annual change in this pattern is predicted to be small. Previous work examining temporal changes in fishing pressure in UK waters found strong spatio-temporal correlation in fishing intensity between 2006 and 2007 (Pearson's r = 0.405, p < 0.001) (Foden et al. 2010). The other human activities are of more restricted spatial extent, e.g. pipelines, dredge disposal licence areas, oil and gas platforms. Therefore the locations and sizes of coincident activities are unlikely to be highly variable over time. To control the consequences of human pressures on the marine environment, it could reasonably be argued that in terms of extent, the assessment and control of spatially limited cumulative impacts is relatively unimportant. The remaining concern relates to consequences of these combined activities on benthic recovery, and the extent to which they are sustainable.

Estimates of recovery rate for single sector activities were $<1$ mo to $9 \mathrm{yr}$, while recovery ranged from 1 to $15 \mathrm{yr}$ for cumulative activities under the 4 scenarios. The largest activity-habitat combinations were beam and otter trawling in sand and gravel, where recovery of the seabed community might reasonably be expected within $1 \mathrm{yr}$. In contrast, the recovery rates from aggregate extraction were substantially greater, although the spatial footprint was very restricted, comprising only $<0.01 \%$ that of benthic fishing. In the small areas where cumulative effects occurred, abrasion and smothering in sand and muddy sand habitats accounted for the majority of coinciding pressures. These pressure-habitat combinations had recovery estimates of up to $5.5 \mathrm{yr}$, while other cumulative impact scenarios suggested the benthic community would require a decade or more to recover. Wherever recovery estimates were $\geq 9 \mathrm{yr}$, aggregate extraction accounted for the largest proportion of that time period.

These results provide quantitative estimates of spatial extent and recovery times of habitats, which are an important addition to the assessment of UK marine ecosystems already undertaken (Defra 2010). This national assessment of benthic habitat condition was based on expert judgement and drew upon limited evidence from monitoring studies and research. Its conclusion states 'large areas of subtidal sediments in most regions have been adversely affected by mobile fishing gears such as bottom trawls and dredges [...] [and] locally, extraction of aggregates has damaged the seabed in the Eastern Channel and Southern North Sea' (Defra 2010, p. 31). Given the large footprint of benthic fishing and the slow recovery rate estimates from aggregate extraction, it might be reasonable, at least in the short term, for management measures to focus on these 2 activities if impact on the seabed is to be mitigated and marine status improved. Indeed, aggregate extraction is already highly regulated and very spatially restricted (DCLG 2002). New statutory 
regulations for aggregate licensing (DCLG 2007) require the Marine Management Organisation to consider the Habitats and Environmental Impacts Assessment Directives (EU 1992, 2003) in their decisions. Consequently, decision-making on site licences is already moving towards an ecosystem approach. Furthermore, it has been argued by some commentators that the loss of seabed can be balanced by the socioeconomic need for aggregate, especially when sites are selected within an ecosystem-based management system (Petterson 2008, Rabaut et al. 2009). This argument is more difficult for extensive activities such as fishing, which is amongst the most important factors affecting the ecological state of many marine ecosystems (Jennings \& Kaiser 1998, Watling \& Norse 1998), and for which management is widely considered to be a high priority (e.g. Pauly et al. 2005, Pitcher \& Lam 2010). However, in the UK there has been a recent move toward regionalisation with the establishment of Regional Advisory Councils, which have the potential to improve fisheries management.

The methodology for analysing individual and cumulative impacts of human activities on the seabed and its application presented herein are likely to be appropriate for other locations. Indeed the literature reviews of recovery rates, here and from previous work (Foden et al. 2009, 2010), included international studies with similar environmental conditions to the UK, based on this a priori assumption. Waters of the wider European region have comparable pressures as well as environmental characteristics to the UK, and similar responses to those pressures would be expected. The basic framework would also be amenable for use in examining the impact of different kinds of pressures affecting regions of contrasting environmental conditions, although literature reviews or empirical studies of pressure effects would need to be focused on the same characteristics of the region under investigation.

Cumulative impact assessment as a discipline is still in its early stages. Recent studies have mapped spatial extent and intensity of multiple human activities (e.g. Ban \& Alder 2008, Halpern et al. 2008b, Selkoe et al. 2009), but few have considered their impact on the receiving habitat (e.g. Ban et al. 2010). These studies are at a variety of scales and in all cases identified greater proportions of overlapping pressures than in this study, generally because they considered pressures on the entire marine ecosystem such as shipping, recreation, aquaculture, and pelagic fishing. Our detailed, quantitative study is an important step on which a holistic ecosystem assessment could be based. However, the more complex and highly integrated the assessment, the more difficult it can be to indicate causality and to predict future scenarios (Foden et al. 2008). For example, recent assessments using multiple parameters to model present and future states are variable in producing quantitative or qualitative conclusions (e.g. Culp et al. 2000, Link et al. 2002, Choi et al. 2005, Chang et al. 2008), which can have consequences for management practices. A compromise is needed between the complexity of a fully integrated ecosystem assessment and its utility for directing management.

There are limitations to this work, for example related to the quality of broad scale habitat maps and the lack of ground-truthing of recovery times, which have been faced by many previous regional scale assessments (e.g. Halpern et al. 2009, Ban et al. 2010). Recovery rates for single activities, summarised in Table 4, are based on empirical evidence, but there are too few studies of recovery from the effects of combinations of activities to estimate recovery. For this reason we presented 4 scenarios of cumulative effects from multiple activities. Ideally the scenarios would also have been run to investigate cumulative impact from repeat events of the same activity. However, it was not possible to present this within the confines of a single paper, although it would be an interesting area for future study. The use of confidence ratings for our data has been a useful step, particularly for those activities for which the exact locations or the spatial extent of their impact was unknown. Confidence was generally low where generic spatial dimensions were used, e.g. for cuttings piles (sensu Eastwood et al. 2007). In reality a markedly patchy distribution of cuttings around production platforms has been noted, depending on site-specific sediment grains size and local hydrography (Kingston et al. 1987). Comparative in situ observations of cuttings from oil and gas production would improve size estimates of area affected and biological impacts from smothering, by habitat type. Similarly, the development of scour pits around turbines will be in the direction of local, prevailing hydrodynamics and such site-specificity could not be taken into account for each structure.

Finally, we assumed that recovery of the natural benthic community could not take place where obstructions were present. However, it is possible that some structures, such as surface-laid cables and pipelines, have either self-buried or are themselves used as a structure for future colonisation. Nevertheless, they might also be subject to damage and therefore be re-exposed for maintenance, and it was not possible to account for these differences in our analyses. Other semi-permanent structures such as wellheads, wrecks, and turbines might provide a hard substrate offering new habitat for benthic fauna and flora (Kogan et al. 2004, 2006, Danish Energy Authority 2006). Such subtle changes in habitat can have implications for higher trophic levels by providing shelter 
and feeding opportunities for predators. There is some evidence that the artificial reefs created by obstructions such as offshore wind farms can enhance fish populations in 2 ways, by increasing the availability of prey species living on the turbines and excluding some types of fishing activity from the region effectively creating a no-take zone (Punt et al. 2009, Reubens et al. 2011). Consideration of these types of trade-offs among different activities may be an interesting extension of cumulative impact assessment. Nonetheless, establishment of fauna associated with these hard substrates represents changes in populations, not reestablishment of the ambient benthic community which we defined as recovery.

The response of the benthic community to all human activity was found to be strongly dependent on the type of receiving habitat. This highlights the necessity for accurate, high resolution habitat maps, essential for more precise estimations of impact for effective management and control (Defra 2010). Similarly, higher resolution spatial data would more closely link activities to the receiving habitat. For example, whilst 2 hourly VMS signals from fishing vessels are suitable for management purposes at the UK scale, for estimating cumulative effects more frequent data would improve the accuracy in locating coinciding activities. Further scientific observations of the immediate and long-term footprint on the benthos from all human activities are necessary to determine which of the 4 scenarios is the most likely in the natural environment.

This work is a rigorous, quantitative assessment of direct individual and cumulative anthropogenic impacts on the seabed. It contributes towards understanding the links between humans and the marine environment by assessing the spatial and temporal effects of anthropogenic activities on the benthos. For future assessment and management purposes, in terms of the impact we have examined in this UK-based study, perhaps the most significant finding is that cumulative pressures on the seabed were very spatially restricted in 2007. Recovery times were comparable to some single sectors; therefore, single sector activities remain the predominant cause of direct human impact on the benthos. Nevertheless, there is still a need to develop scientific understanding of the linkages across those aspects of the marine environment not considered herein, e.g. water column pollution, pelagic fisheries, shipping and underwater noise. How such considerations might modify our findings is yet to be determined. To implement a full ecosystembased approach to management would require a coherent and holistic assessment of all such interconnections, some of which may lead to cumulative impacts greater than those we have been able to consider (Foden et al. 2008). Nevertheless, we have addressed some of the knowledge, data and assessment tool gaps identified in recent national status assessments (Defra 2010), with regard to human pressure and impact on the benthic community. We hope that this approach to assessing the state of marine habitats will enable a more quantitative approach in future reporting against European and international commitments.

Acknowledgements. We thank R. Hill at BT Design and J. Lee, S. Pacitto and A. Birchenough at Cefas for their support with information, data and GIS. This work was funded by a Natural Environment Research Council (NERC) studentship, a Cefas CASE award and by the Department for Environment Food and Rural Affairs (Defra) research contract AE1148.

\section{LITERATURE CITED}

Allan PG (1998) Geotechnical aspects of submarine cables. IBC Conference on Subsea Geotechnics, Aberdeen, November 1998. Available at www.setech-uk.com/pdf/ paper2.pdf

> Andrulewicz E, Napierska D, Otremba Z (2003) The environmental effects of the installation and functioning of the submarine SwePol Link HVDC transmission line: a case study of the Polish Marine Area of the Baltic Sea. J Sea Res 49:337-345

Ban N, Alder J (2008) How wild is the ocean? Assessing the intensity of anthropogenic marine activities in British Columbia, Canada. Aquat Conserv 18:55-85

Ban NC, Alidina HM, Ardron JA (2010) Cumulative impact mapping: Advances, relevance and limitations to marine management and conservation, using Canada's Pacific waters as a case study. Mar Policy 34:876-886

Birchenough AC, Bolam SG, Bowles GM, Hawkins B, Whomersley P, Weiss L (2010) Monitoring of dredged material disposal licences at sea and how it links to licensing decisions. 32nd PIANC Congress: Setting the course. Liverpool 2010

BMAPA (British Marine Aggregate Producers Association) (2006) Aggregates from the sea. BMAPA, London

BMAPA (British Marine Aggregate Producers Association) (2008) The area involved 10th annual report. BMAPA, London

Bolam SG, Rees HL (2003) Minimizing impacts of maintenance dredged material disposal in the coastal environment: a habitat approach. Environ Manage 32:171-188

Bolam SG, Rees HL, Somerfield P, Smith R and others (2006) Ecological consequences of dredged material disposal in the marine environment: a holistic assessment of activities around the England and Wales coastline. Mar Pollut Bull 52:415-426

> Borja A, Muxika I, Rodríguez JG (2009) Paradigmatic responses of marine benthic communities to different anthropogenic pressures, using M-AMBI, within the European Water Framework Directive. PSZN I: Mar Ecol 30:214-227

Boyd SE, Cooper KM, Limpenny DS, Kilbride R and others (2004) Assessment of the rehabilitation of the seabed following marine aggregate dredging. Sci Ser Tech Rep 121, Cefas, Lowestoft

Breuer E, Stevenson AG, Howe JA, Carroll J, Shimmield GB (2004) Drill cutting accumulations in the northern and central North Sea: a review of environmental interactions and chemical fate. Mar Pollut Bull 48:12-25 
Carter L, Burnett D, Drew S, Marle G, Hagadorn L, BartlettMcNeil D, Irvine N (2009) Submarine cables and the oceans - connecting the world. UNEP-WCMC Biodiversity Series No. 31. ICPC/UNEP/UNEP-WCMC

Cefas (Centre for Environment, Fisheries and Aquaculture Science) (2010) Strategic review of offshore wind farm monitoring data associated with FEPA licence conditions. Project code ME1117. Department for the Environment, Food and Rural Affairs (Defra), London

Chang YC, Hong FW, Lee MT (2008) A system dynamic based DSS for sustainable coral reef management in Kenting coastal zone, Taiwan. Ecol Model 211:153-168

Choi JS, Frank KT, Petrie BD, Leggett WC (2005) Integrated assessment of a large marine ecosystem: a case study of the devolution of the Eastern Scotian Shelf, Canada. Oceanogr Mar Biol Annu Rev 43:47-67

Collie JS, Escanero GA, Valentine PC (1997) Effects of bottom fishing on the benthic megafauna of Georges Bank. Mar Ecol Prog Ser 155:159-172

Collie JS, Hall SJ, Kaiser MJ, Poiner IR (2000) A quantitative analysis of fishing impacts on shelf-sea benthos. J Anim Ecol 69:785-799

Cooper KM, Boyd SE, Eggleton JE, Limpenny DS, Rees H, Vanstaen K (2007) Recovery of the seabed following marine aggregate dredging on the Hastings Shingle Bank. Estuar Coast Shelf Sci 75:547-558

Crain CM, Kroeker K, Halpern BS (2008) Interactive and cumulative effects of multiple human stressors in marine systems. Ecol Lett 11:1304-1315

Culp JM, Cash KJ, Wrona FJ (2000) Cumulative effects assessment for the Northern River Basins Study. J Aquat Ecosyst Stress Recovery 8:87-94

Currie DR, Isaacs LR (2005) Impact of exploratory offshore drilling on benthic communities in the Minerva gas field, Port Campbell, Australia. Mar Environ Res 59:217-233

Daan R, Mulder M (1996) On the short-term and long-term impact of drilling activities in the Dutch sector of the North Sea. ICES J Mar Sci 53:1036-1044

> Daan R, Mulder M, Van Leeuwen A (1994) Differential sensitivity of macrozoobenthic species to discharges of oil-contaminated drill cuttings in the North Sea. Neth J Sea Res 33:113-127

Danish Energy Authority (2006) Offshore windfarms and the environment: Danish experiences from Horns Rev and Nysted. Danish Energy Authority, Copenhagen. Available at http://ens.netboghandel.dk

Darling ES, Côté IM (2008) Quantifying the evidence for ecological synergies. Ecol Lett 11:1278-1286

DCLG (Department for Communities and Local Government) (2002) Marine Mineral Guidance 1: Extraction by dredging from the English seabed. Defra, London

DCLG (Department for Communities and Local Government) (2007) The Environmental Impact Assessment and Natural Habitats (Extraction of Minerals by Marine Dredging) (England and Northern Ireland) Regulations 2007, Environmental Protection No. 1067. Defra, London

de Groot SJ (1996) Quantitative assessment of the development of the offshore oil and gas industry in the North Sea. ICES J Mar Sci 53:1045-1050

Defra (Department for Environment, Food and Rural Affairs) (2005) Charting Progress: an integrated assessment of the state of the seas. Defra, London

Defra (Department for Environment, Food and Rural Affairs) (2010) Charting Progress 2: an assessment of the state of the seas. Defra, London

Degraer S, Brabant R (eds) (2009) Offshore wind farms in the Belgian part of the North Sea: state of the art after two years of environmental monitoring. Royal Belgian Institute for Natural Sciences/Management Unit of the North Sea Mathematical Models. Marine Ecosystem Management Unit, Brussels. Available at www.vliz.be/ imis/imis.php? module $=$ ref\&refid $=142990$

Desprez M (2000) Physical and biological impact of marine aggregate extraction along the French coast of the Eastern English Channel short-and long-term post-dredging restoration. ICES J Mar Sci 57:1428-1438

Dickson RR, Lee A (1972) Study of effects of marine gravel extraction on the topography of the seabed. ICES CM1972/E:25

> Dinmore TA, Duplisea DE, Rackham BD, Maxwell DL, Jennings $S$ (2003) Impact of a large-scale area closure on patterns of fishing disturbance and the consequences for benthic communities. ICES J Mar Sci 60:371-380

Drew SC, Hopper AG (2009) Fishing and submarine cables working together, 2nd edition. International Cable Protection Committee, Lymington

Eastwood PD, Mills CM, Aldridge JN, Houghton CA, Rogers SI (2007) Human activities in UK offshore waters: an assessment of direct, physical pressure on the seabed. ICES J Mar Sci 64:453-463

EEA (European Environment Agency) (2004) EUNIS habitat classification revised. Available at http://eunis.eea.europa. eu/upload/EUNIS_2004_report.pdf

EU (European Union) (1992) Council Directive 92/43/EEC of 21 May 1992 on the conservation of natural habitats and of wild fauna and flora (Habitats Directive). Off J Eur Union L206:7-50

EU (European Union) (2000) Directive 2000/60/EC of the European Parliament and of the Council of 23 October 2000 establishing a framework for community action in the field of water policy (Water Framework Directive). Off J Eur Union L327:1-73

EU (European Union) (2003) Directive 2003/35/EC of 26 May 2003 providing for public participation in respect of the drawing up of certain plans and programmes relating to the environment and amending with regard to public participation and access to justice Council Directives 85/337/EEC and 96/61/EC - statement by the Commission. Off J Eur Union L156:17-25

EU (European Union) (2008) Directive 2008/56/EC of the European Parliament and of the Council of 17 June 2008 establishing a framework for community action in the field of marine environmental policy (Marine Strategy Framework Directive). Off J Eur Union L164:19-40

EU (European Union) (2010) Directive 2009/147/EC of the European Parliament and of the Council of 30 November 2009 on the conservation of wild birds (Birds Directive). Off J Eur Union L20:7-25

Foden J, Rogers SI, Jones AP (2008) A critical review of approaches to aquatic environmental assessment. Mar Pollut Bull 56:1825-1833

> Foden J, Rogers SI, Jones AP (2009) Recovery rates of UK seabed habitats after cessation of aggregate extraction. Mar Ecol Prog Ser 390:15-26

Foden J, Rogers SI, Jones AP (2010) Recovery of UK seabed habitats from benthic fishing and aggregate extractiontowards a cumulative impact assessment. Mar Ecol Prog Ser 411:259-270

Folk RL (1954) The distinction between grain size and mineral composition in sedimentary-rock nomenclature. J Geol 62: $344-359$

Folt CL, Chen CY, Moore MV, Burnaford J (1999) Synergism and antagonism among multiple stressors. Limnol Oceanogr 44:864-877 
Gilkinson KD, Gordon DC Jr, MacIssac KG, McKeown DL, Kenchington ELR, Bourbonnais C, Vass WP (2005) Immediate impacts and recovery trajectories of macrofaunal communities following hydraulic clam dredging on Banquereau, eastern Canada. ICES J Mar Sci 62:925-947

- Guerra-García JM, García-Gómez JC (2006) Recolonization of defaunated sediments: Fine versus gross sand and dredging versus experimental trays. Estuar Coast Shelf Sci 68:328-342

Hall SJ (1994) Physical disturbance and marine benthic communities: life in unconsolidated sediments. Oceanogr Mar Biol Annu Rev 32:179-239

Hall K, Paramor OAL, Robinson LA, Winrow-Giffin A, Frid CLJ (2008) Mapping the sensitivity of benthic habitats to fishing in Welsh waters-development of a protocol. CCW Policy Research Report No.08/12, CCW Bangor

Halpern BS, McLeod KL, Rosenberg AA, Crowder LB (2008a) Managing for cumulative impacts in ecosystem-based management through ocean zoning. Ocean Coast Manage 51:203-211

- Halpern BS, Walbridge S, Selkoe KA, Kappel CV and others (2008b) A global map of human impact on marine ecosystems. Science 319:948-952

Halpern BS, Kappel CV, Selkoe KA, Micheli F and others (2009) Mapping cumulative human impacts to California Current marine ecosystems. Conserv Lett 2:138-148

Hiddink JG, Jennings S, Kaiser MJ (2006a) Indicators of the ecological impact of bottom-trawl disturbance on seabed communities. Ecosystems 9:1190-1199

- Hiddink JG, Jennings S, Kaiser MJ, Queirós AM, Duplisea DE, Piet GJ (2006b) Cumulative impacts of seabed trawl disturbance on benthic biomass, production, and species richness in different habitats. Can J Fish Aquat Sci 63: 721-736

- Hiscock K, Tyler-Walters H (2006) Assessing the sensitivity of seabed species and biotopes - the Marine Life Information Network (MarLIN). Hydrobiologia 555:309-320

$>$ Holdway DA (2002) The acute and chronic effects of wastes associated with offshore oil and gas production on temperate and tropical marine ecological processes. Mar Pollut Bull 44:185-203

Jennings S, Kaiser MJ (1998) The effects of fishing on marine ecosystems. Adv Mar Biol 34:201-352

Kaiser MJ, Edwards D, Armstrong P, Radford K, Lough N, Flatt R, Jones H (1998) Changes in megafaunal benthic communities in different habitats after trawling disturbance. ICES J Mar Sci 55:353-361

Kaiser MJ, Collie JS, Hall SJ, Jennings S, Poiner IR (2002) Modification of marine habitats by trawling activities: prognosis and solutions. Fish Fish 3:114-136

Kaiser MJ, Clarke KR, Hinz H, Austen MCV, Somerfield PJ, Karakassis I (2006) Global analysis of response and recovery of benthic biota to fishing. Mar Ecol Prog Ser 311: $1-14$

Kenchington ELR, Gilkinson KD, Maclsaac KG, BourbonnaisBoyce C, Kenchington TJ, Smith SJ, Gordon DC Jr (2006) Effects of experimental otter trawling on benthic assemblages on Western Bank, northwest Atlantic Ocean. J Sea Res 56:249-270

Kenny AJ, Rees HL (1994) The effects of marine gravel extraction on the macrobenthos: early post dredging recolonisation. Mar Pollut Bull 28:442-447

Kingston PF, Warren LM, Hughes RG, Earll R, Parker JG, Gray JS (1987) Field effects of platform discharges on benthic macrofauna. Philos Trans R Soc Lond B Biol Sci 316: 545-565

Kogan I, Paull CK, Kuhnz LA, Burton EJ, Von Thun S, Greene
HG, Barry JP (2004) Environmental impact of a submarine cable: case study of the ATOC/ Pioneer Seamount cable. Monterey Bay Aquarium Research Institute, Moss Landing, CA. Available at www.mbari.org/earth/2004/ ATOC\%20writeup.pdf

Kogan I, Paull CK, Kuhnz LA, Burton EJ, Von Thun S, Greene HG, Barry JP (2006) ATOC/Pioneer Seamount cable after 8 years on the seafloor: observations, environmental impact. Cont Shelf Res 26:771-787

Kröncke I, Bergfeld C (2003) North Sea benthos; a review. Senckenb Marit 33:205-268

Kröncke I, Duineveld GCA, Raak S, Rachor E, Daan R (1992) Effects of a former discharge of drill cuttings on the macrofauna community. Mar Ecol Prog Ser 91:277-287

Lee J, South AB, Jennings S (2010) Developing reliable, repeatable, and accessible methods to provide highresolution estimates of fishing-effort distributions from vessel monitoring system (VMS) data. ICES J Mar Sci 67: 1260-1271

> Link JS, Brodziak JKT, Edwards SF, Overholtz WJ and others (2002) Marine ecosystem assessment in a fisheries management context. Can J Fish Aquat Sci 59:1429-1440

Newell RC, Seiderer LJ, Hitchcock DR (1998) The impact of dredging works in coastal waters: a review of the sensitivity to disturbance and subsequent recovery of biological resources on the sea bed. Oceanogr Mar Biol Annu Rev 36:127-178

NPower Renewables (2008) North Hoyle offshore wind farm: final annual FEPA monitoring report (2006-7) \& five year monitoring programme summary. NH/FEPA/200607, NPower, Swindon

OSPAR Commission (1993) The use of oil-based muds. PARCOM Decision 92/2. OSPAR, London

OSPAR Commission (2000) The use of organic-phase drilling fluids (OPF) and the discharge of OPF-contaminated cuttings. Decision 2000/3. OSPAR, London

OSPAR Commission (2006) Review of the current state of knowledge on the environmental impacts of the location, operation and removal/disposal of offshore wind-farms. Publication no. 278/2006. OSPAR, London

OSPAR Commission (2008) Assessment of the environmental impact of offshore wind-farms. Publication no. 385/2008. OSPAR, London

OSPAR Commission (2009) Assessment of impacts of offshore oil and gas activities in the North-East Atlantic. Publication no. 453/2009. OSPAR, London

> Pauly D, Watson R, Alder J (2005) Global trends in world fisheries: impacts on marine ecosystems and food security. Philos Trans R Soc B 360:5-12

- Petterson MG (2008) Minerals sustainability, emerging economies, the developing world and the 'truth' behind the rhetoric. Est J Earth Sci 57:57-74

Pitcher TJ, Lam ME (2010) Fishful thinking: rhetoric, reality, and the sea before us. Ecology Soc 15(2):12. Available at www.ecologyandsociety.org/vol15/iss2/art12/

Pitcher CR, Burridge CY, Wassenberg TJ, Hill BJ, Poiner IR (2009) A large scale BACI experiment to test the effects of prawn trawling on seabed biota in a closed area of the Great Barrier Reef Marine Park, Australia. Fish Res 99: 168-183

Punt MJ, Groeneveld RA, van Ierland EC, Stel JH (2009) Spatial planning of offshore wind farms: a windfall to marine environmental protection? Ecol Econ 69:93-103

Rabaut M, Degraer S, Schrijvers J, Derous S and others (2009) Policy analysis of the 'MPA-process' in temperate continental shelf areas. Aquat Conserv 19:596-608

Ragnarsson SA, Lindegarth M (2009) Testing hypothesis about 
temporary and persistent effects of otter trawling on infauna: changes in diversity rather than abundance. Mar Ecol Prog Ser 385:51-64

Rees J (2006) Scroby Sands offshore wind farm — coastal processes monitoring. Final report for the Department of Trade and Industry. Project Code AE0262, Cefas, Lowestoft

Reubens JT, Degraer S, Vincx M (2011) Aggregation and feeding behaviour of pouting (Trisopterus luscus) at wind turbines in the Belgian part of the North Sea. Fish Res 108: 223-227

Rijnsdorp AD, Buys AM, Storbeck F, Visser EG (1998) Microscale distribution of beam trawl effort in the southern North Sea between 1993 and 1996 in relation to the trawling frequency of the sea bed and the impact on benthic organisms. ICES J Mar Sci 55:403-419

Selkoe KA, Halpern BS, Ebert CM, Franklin EC and others (2009) A map of human impacts to a 'pristine' coral reef ecosystem, the Papahānaumokuākea Marine National Monument. Coral Reefs 28:635-650

Sparks-McConkey PJ, Watling L (2001) Effects on the ecological integrity of a soft-bottom habitat from a trawling disturbance. Hydrobiologia 456:73-85

Stelzenmüller V, Rogers SI, Mills CM (2008) Spatio-temporal patterns of fishing pressure on UK marine landscapes and their implications for spatial planning and management. ICES J Mar Sci 65:1081-1091

Stelzenmüller V, Lee J, South A, Rogers SI (2010) Quantifying cumulative impacts of human pressures on the marine environment: a geospatial modelling framework. Mar Ecol Prog Ser 398:19-32

Trannum HC, Nilsson HC, Schaanning MT, Øxnevad S (2010)

Editorial responsibility: Jake Rice,

Ottawa, Ontario, Canada
Effects of sedimentation from water-based drill cuttings and natural sediment on benthic macrofaunal community structure and ecosystem processes. J Exp Mar Biol Ecol 383:111-121

UKOOA (2002) Britain's offshore oil and gas, 2nd edn. United Kingdom Offshore Operators Association, London

UNEP (United Nations Environment Programme) (1992) Convention on Biological Diversity, Rio de Janeiro, Brasil. UNEP Document no. Na.92-78. UNEP, Nairobi

Watling L, Norse EA (1998) Disturbance of the seabed by mobile fishing gear: a comparison to forest clearcutting. Conserv Biol 12:1180-1197

- Whomersley P, Huxham M, Bolam S, Schratzberger M, Augley J, Ridland D (2010) Response of intertidal macrofauna to multiple disturbance types and intensities - an experimental approach. Mar Environ Res 69:297-308

Wilber DH, Ray GL, Clarke DG, Diaz RJ (2008) Responses of benthic infauna to large-scale sediment disturbance in Corpus Christi Bay, Texas. J Exp Mar Biol Ecol 365: $13-22$

Wilson SJK, Fredette TJ, Germano JD, Blake JA, Neubert PLA, Carey DA (2009) Plan-view photos, benthic grabs, and sediment-profile images: using complementary techniques to assess response to seafloor disturbance. Mar Pollut Bull 59:26-37

Zuvo M, Bjørnbom E, Ellingsen B, Buffagni M, Kelley A, Trannum HC (2005) High resolution environmental survey around an exploration well drilled with formate brine in the Barents Sea, Norway. Paper SPE 94477, presented at the 2005 SPE Exploration and Production Environmental Conference, Galveston, TX, 7-9 March 2005

Submitted: November 22, 2010; Accepted: January 27, 2011 Proofs received from author(s): April 15, 2011 